\title{
Learning innovation on mechanical engineering vocational education in the new normal era
}

\author{
Puteri Anggieta Cahyani *, Widarto Widarto, Olivia Laras Sati \\ Universitas Negeri Yogyakarta. \\ Jl. Colombo No.1, Caturtunggal, Depok, Sleman, Daerah Istimewa Yogyakarta 55281, Indonesia. \\ *Corresponding Author. Email: puterianggieta.2019@student.uny.ac.id
}

\section{ARTICLE INFO \\ Article History \\ Received: \\ 15 December 2020; \\ Revised: \\ 11 January 2021; \\ Accepted: \\ 18 January 2021; \\ Available online: \\ 28 July 2021}

\section{Keywords}

Innovation learning;

New normal;

Vocational education;

\begin{abstract}
This study explores the implementation of vocational learning in the new normal era related to the content, assignment forms, and class management and describes teacher innovations and hope. The research was conducted using a quantitative descriptive approach with a research instrument is a questionnaire. The questionnaire was given to 46 respondents consisting of mechanical engineering vocational teachers from several regions in Indonesia. The questionnaire consists of two categories, namely statements with an option and statements with open answers. The findings of this study are based on two categories, namely theoretical and practical learning. The results reveal that in theory learning, teachers prefer to share material with students in various forms, including PDF, PPT, Video, and others $(17.56 \%)$, assigning forms in summarizing material $(25.19 \%)$, and with the full class $(47.78 \%)$. Whereas in practical learning, the teacher conducted learning with a system block $(5.85 \%)$, gave assignments in the form of making projects or products $(6.93 \%)$, and with half-class management combined with online classes $(7.78 \%)$. Another finding is the innovation applied by teachers is developing technology-based learning materials and using online platforms. In the learning situation of the new era, normal teachers expect a flexible curriculum and standardized, effective, and efficient media, models, methods, and learning platforms. In the learning practice, the teacher expects practice videos and simulation applications that are expected to be followed under the expected basic competencies and equipped with learning practices with the application of health protocols and the number of students.
\end{abstract}

This is an open access article under the $\underline{\mathrm{CC}-\mathrm{BY}-\mathrm{SA}}$ license.

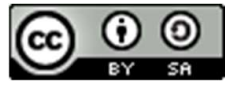

How to cite:

Cahyani, P. A., Widarto, W., \& Sati, O. L. (2021). Learning innovation on mechanical engineering vocational education in the new normal era. Jurnal Pendidikan Vokasi, 11(1), 24-32. https://doi.org/10.21831/jpv.v11i1.36597

\section{INTRODUCTION}

The rapid development of technology in the industrial revolution 4.0 era significantly impacted each aspect of life, including education. The education system in the industrial revolution 4.0 era has a special characteristic that differentiates it from the previous education systems, especially in the learning process. In the industrial revolution 4.0 era, technology is utilized in each learning process (Lase, 2019). It can be implied that the learning process should move from conventional learning to technology-based learning.

Some learning resources that can be accessed due to the development of technology impact the perception that the teacher is not the only learning source. The changes in the learning pattern from teacher-centered into student-centered in curriculum 2013 have demanded the students to 
search for various information more actively in the learning process. In addition, the current learning system has implemented context-based learning that aims to correlate the learning material with students' daily life. In accommodating the changes in the learning system, the teachers need a medium for delivering the learning material effectively, such as technology-based learning media.

However, based on the results of preliminary interviews with teachers at SMK Negeri 8 Medan, it is known that in the learning process, teachers still apply conventional methods. The facilities provided in the laboratory, such as computers and LCDs, have not been fully utilized in the learning process. This has an impact on low student achievement. The results of student exams on the chicken carcass material were not satisfactory because the number of students who passed the Minimum Completeness Criteria (KKM) was only 14 students, or only $41 \%$ of the total students in the class ( 34 students). This is evidenced by the results of interviews with students who stated that they still had difficulty distinguishing some parts of the chicken carcass and how to cut them properly and appropriately. In connection with this information, appropriate media is needed that can meet the needs of students. An alternative media used in student culinary learning is audiovisual media, especially on chicken carcass material.

Culinary is one of the majors provided at SMK. Culinary majors students have the same learning characteristics as students at other SMK. The learning system in SMK emphasizes mastery of learning material and practicum as basic knowledge for students when entering the real world of work. It is in line with Budiman, Soesanto, and Widjanarko (2017), which states that SMK emphasizes the ability to master knowledge, skills, attitudes, and several values in the real world. Therefore, several media are needed in the learning process because the learning system is dominated by practice to support the practical fieldwork process, and students can achieve goals systematically Arfika and Chalid (2017). One of the learning media that can be used to accommodate student needs is audiovisual media. Ashaver and Igyuve (2013); Olube (2015) specifically defines audiovisual media as media in software and hardware, which can increase student motivation in the learning process supported by instructions on the media. There are two main elements in audiovisual media, namely audio and visual elements (Desrianti et al., 2011). Hughes, Costley, and Lange (2019) stated that audio and visual elements in audiovisual media could accommodate the information needed by students and the effectiveness of learning with several stimuli. The stimulus can help students understand the material easily. Based on the research results, audiovisual media positively affects student learning outcomes on chicken carcass material.

Therefore, some audiovisual media have been developed for teaching chicken carcass material. Audiovisual media belong to a group of media that can visualize the material and provide sound at the same time (Rupawati et al., 2017). The term audiovisual refers to the instructional media that can be used in delivering meaning without any interdependence with the symbol or language (Anzaku, 2011). The learning materials in audiovisual media are related to the information about material and tools, system, or the information that can be practiced since the instructions are provided. Audiovisual media play several roles in the learning process, such as emphasizing the lessons obtained from experience-enhancing students' experiences, attracting students' participation, stimulating students' motivation, doing the instruction independently since it contains the source of information, and creating meaningful learning (Ashaver \& Igyuve, 2013). These important roles of audiovisual media are in line with (Chieke et al., 2017). In general, acquiring information is mostly dominated by visual and hearing senses (visualization and audio).

The effectiveness of audiovisual media in improving students' learning outcomes had been conducted by Sugiani, Syahbudi, and Handayani (2020) by using audiovisual media in teaching the students of the mechanical engineering department, and the results of the research proved that audiovisual medium was effective in improving students' learning outcomes. In addition, the research conducted by (Seçer et al., 2015) had also proved that using audiovisual media in the learning process can give a positive result in improving students' motivation, as well as resulting in positive learning outcome. Ode (2014) stated that in improving students' learning motivation by using audiovisual media, the abstract concept could be turned into the concrete ones. The students can understand the material easily. In addition, by using audiovisual media, the students can enjoy the learning process better (Kausar, 2013). 
Based on the background, this study focused on identifying the effectiveness of audiovisual media in improving students' learning outcomes at the tenth-grade students of Culinary Department, in chicken carcass material. This research aimed to contribute to the culinary teachers in obtaining a reference related to the effective learning media for supporting the culinary teaching and learning process. Furthermore, the audiovisual medium can be used as the reference in chicken carcass material to enhance innovations in the learning process. By using suitable media, hopefully, can have positive influences on students' learning outcomes.

\section{RESEARCH METHOD}

The research was conducted using a quantitative descriptive approach to describe the results (Apuke, 2017). The Population in this study involved vocational education teachers in mechanical engineering. The sampling technique in this study is purposive sampling which aims to obtain more representative data. Forty-six teachers participated in this study. The data were collected by giving a questionnaire to respondents of vocational teachers of mechanical engineering through a Google Form, which the respondents filled in online. The questionnaire consisted of ordinal data and open statements by the teacher (Osuagwu, 2020). The ordinal data is converted into a percentage to describe the implementation of learning, including content, assignment form, and task management. Meanwhile, open statements describe the learning innovations that teachers have carried out and describe teacher perceptions in the new normal era of learning.

The researchers analyzed the data using two stages. First, the researchers conducted data analysis using ordinal data to describe the implementation of learning. Second, researchers used open statements to describe learning innovations and teacher expectations in the new normal era of learning. Researchers conducted data analysis using ordinal data to describe the implementation of learning. Data analysis regarding the implementation of learning includes 1.) Describing the implementation of learning related to learning content, assignment forms, and class management displayed in chart form; and 2.) Describe the implementation of learning from ordinal data that has been obtained from the research. Data is converted into percentages and displayed in table form to find the implementation of learning most widely used by teachers in learning in the new normal era.

Researchers use open statements to describe learning innovations and teacher perceptions of learning in the future in the new normal era of learning. The results data are displayed descriptively to provide opportunities for teachers to express opinions and then conclude various learning innovations and teacher expectations on the implementation of vocational education in the new normal era.

\section{RESULT AND DISCUSSION}

\section{Implementation of Learning in The New Normal Era}

Learning in the new normal era is an important thing that is expected to achieve educational goals. Learning requires a series system that can convey knowledge and increase student competence. In learning Mechanical Engineering in Vocational High Schools, various aspects need to be considered, especially practical learning. The New Normal Era caused different teachers' perceptions of learning in the future, its implementation. The questionnaire that was distributed to 46 respondents resulted in four important points in learning, namely online theory learning, offline theory, online practice, and offline practice. Each teacher applies a different learning system with their respective school policies. Some teachers still apply one lesson only, while others have applied to learn both theory and practice and online and offline.

Researchers conducted a study of learning, assignment forms, and classroom management in the New Normal era of the four learning categories found. This is based on important aspects of learning. Many teachers are still confused about the application of learning, so the researchers take these data to conclude some aspects that the teacher in learning has applied. The results of the researchers' findings can be seen in Figure 1. 


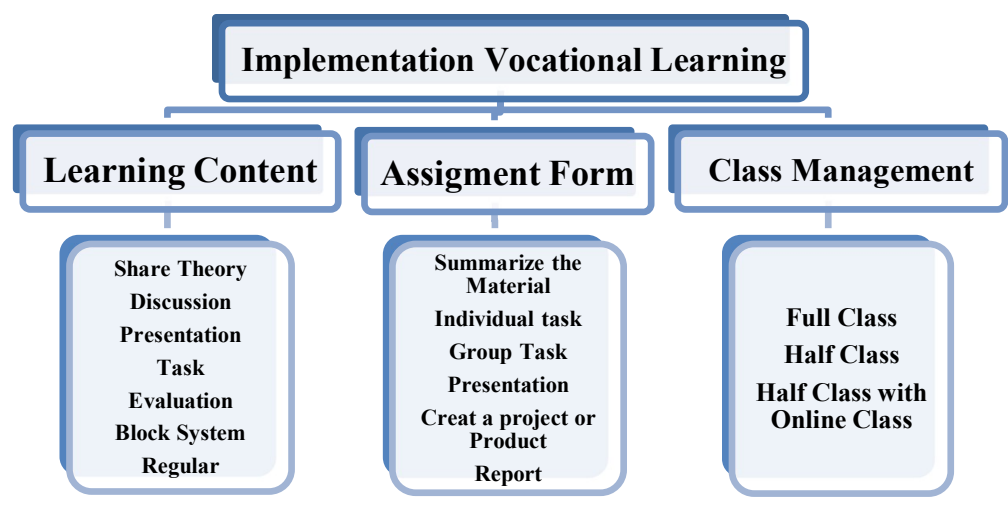

Figure 1. Finding Research

\section{Learning Content}

Learning requires content or material that students can take as information related to their knowledge. In line with that, the learning content also needs to be conveyed optimally. The teacher gives the form of implementation of learning to students in several ways that are tailored to the learning categories used by the teacher (Sargin et al., 2015). A total of 46 respondents, there were four categories of the implementation of learning, it can be seen in Table 1.

Table 1. Category of Learning Implementation

\begin{tabular}{ccc}
\hline Codes & Learning Implementation & $\mathrm{f}$ \\
\hline M1 & Online theory learning & 46 \\
M2 & Offline theory learning & 14 \\
M3 & Online practical learning & 16 \\
M4 & Offline practical learning & 17 \\
\hline
\end{tabular}

(Source: Result of data analysis, 2020)

Table 2. Learning Content

\begin{tabular}{clcccc}
\hline \multirow{2}{*}{ Num } & \multicolumn{1}{c}{ Learning Content } & M1 & $\mathrm{M} 2{ }^{2}(\%)$ & $\mathrm{M} 3$ & $\mathrm{M} 4$ \\
\hline 1 & Share Theory & 17,56 & 4,48 & 5,41 & - \\
2 & Discussion & 5,41 & 1,21 & 1,21 & - \\
3 & Presentation & 8,96 & 1,21 & 2,14 & - \\
4 & Task & 11,68 & 5,41 & 4,48 & - \\
5 & Evaluation (quizzes and tests) & 16,58 & 2,68 & 3,59 & - \\
6 & Block System & - & - & - & 5,85 \\
7 & Reguler & - & - & - & 2,14 \\
& Total & 60,19 & 14,99 & 16,83 & 7,99 \\
\hline
\end{tabular}

(Source: Result of data analysis, 2020)

The content of learning that teachers in the new normal era have carried out identifies that learning is carried out in various ways (as presented in Table 2). Subjects consist of the Basic Mechanical Engineering Expertise Program, Competency of Mechanical Engineering Expertise, and others. Researchers found that in online theory learning, vocational teachers prefer to share theory in the form of PDF, E-modules, and others (17.56\%). After giving the material, students are directed to study both with the teacher's assistance and independently. In online theory learning, the content of learning is given to students through assignments $(5.41 \%)$, while in online and offline practice implementation, each uses share theory $(5.41 \%)$ and uses a system block at the end of learning (5.85\%). Online learning is done by sharing theory (PDF, E-module, PPT, video, and others) (Gohiya 
\& Gohiya, 2020), while offline learning is carried out with assignments and a block system at the end of the semester.

\section{Assignment Form}

The assignment is one of the learning steps used by the teacher in carrying out learning in the new normal era. Assignments are considered effective in implementing independent learning by students and learning provided by the teacher. The assignment is also related to the assessment that the teacher will carry out so that assignments that can be done using various media and methods can be used effectively and efficiently within the limited time and distance created by the Covid-19 pandemic. The following are the findings regarding the form of the assignment carried out by the teacher in Table 3.

Table 3. Assignment Form

\begin{tabular}{|c|c|c|c|c|c|}
\hline \multirow{2}{*}{ Num } & \multirow{2}{*}{ Task Form } & \multicolumn{4}{|c|}{$\mathrm{f}(\%)$} \\
\hline & & M1 & M2 & M3 & M4 \\
\hline 1 & Summarize the material & 25,19 & 2,79 & - & - \\
\hline 2 & Individual task & - & 7,63 & - & 4,89 \\
\hline 3 & Group task & 8,38 & 2,79 & 6,27 & - \\
\hline 4 & Presentation & - & 1,43 & 2,17 & - \\
\hline 5 & Create a Project or Product & 11,91 & 4,89 & 6,93 & 5,64 \\
\hline \multirow[t]{2}{*}{6} & Report & - & - & - & 9,07 \\
\hline & Total & 45,50 & 19,53 & 15,37 & 19,60 \\
\hline
\end{tabular}

(Source: Result of data analysis, 2020)

There are six forms of assignment carried out by vocational teachers. The teacher gives assignments in the form of summarizing material $(25.19 \%)$ that the teacher has given in online theory learning. Offline teacher learning theory uses assignments in the form of individual assignments (7.63\%). The implementation of online practical learning is carried out by giving the task of making projects or products related to their respective subjects $(6.93 \%)$. And in offline practical learning, the teacher gave assignments in the form of reports $(9.07 \%)$.

\section{Class Management}

Class management in the new normal era made teachers more complex. In online learning, the teacher chooses to teach classes with a full class system because all students can reach it. Whereas in offline learning, teachers are limited to government and school policies, and the need for implementing health protocols and limiting the number of students makes some teachers ambiguous (Lassoued et al., 2020). Class management is carried out by considering the competencies that will be achieved in learning (Cristea, 2015). some schools implemented a block system in practical learning as well, as in a preliminary study, several schools implemented a block system in practical learning in the pandemic era (Burhan \& Arifin, 2020).

Table 4. Class Management

\begin{tabular}{|c|c|c|c|c|c|}
\hline \multirow{2}{*}{ Num } & \multirow{2}{*}{ Class Management } & \multicolumn{4}{|c|}{$f(\%)$} \\
\hline & & M1 & M2 & M3 & $\mathrm{M} 4$ \\
\hline 1 & Full Class & 47,78 & 3,33 & 17,78 & 4,44 \\
\hline 2 & Half Class & - & 3,33 & - & 6,67 \\
\hline 3 & Half Class with Online Class & - & 8,89 & - & 7,78 \\
\hline & Total & 47,78 & 15,55 & 17,78 & 18,89 \\
\hline
\end{tabular}

(Source: Result of data analysis, 2020)

The results of the research found in Table 4 state that in the implementation of offline theory and practice learning the teacher chose to use a half-class system with student restrictions and combined it with online classes with the rest of the students who did not practice offline. The 
percentage of results was $8.89 \%$ and $7.78 \%$, respectively. This identifies that offline learning is still constrained by the provisions that the teacher must apply.

\section{Innovation and Teacher Perception of learning in the future in the New Normal Era}

The instrument for filling out the questionnaire that the teacher has carried out will be categorized based on the characteristics of implementing theoretical and practical learning both online and offline. The teacher's learning innovations can be used as an example for other mechanical engineering vocational teachers in implementing learning in the new normal era. Teachers' hopes can be collected as input and solutions by the government and schools in developing future learning in the Covid-19 pandemic situation. The questionnaire given was in the form of a direct statement that the teacher filled in, and then the researchers described it as.

Table 5. Innovation and Teacher Perception of Learning in Future

\begin{tabular}{|c|c|c|c|}
\hline Num & $\begin{array}{c}\text { Learning } \\
\text { Implementation }\end{array}$ & Innovation & Teacher Perception of Learning in Future \\
\hline 1. & $\begin{array}{l}\text { Theoretical } \\
\text { Learning }\end{array}$ & $\begin{array}{l}\text { 1. Create material in the form of PDF, PPT, } \\
\text { e-module, and assignments which are then } \\
\text { explained and/or given to students online } \\
\text { (google classroom, WAG, zoom, and } \\
\text { others) } \\
\text { 2. Giving assignments and quizzes in } \\
\text { assessing the learning that has been } \\
\text { implemented. } \\
\text { 3. Creating student Learning Journal. } \\
\text { 4. Using a problem-based learning model } \\
\text { 5. Provide opportunities for students to } \\
\text { discuss and presentations. } \\
\text { 6. Learning is done by using a problem- } \\
\text { based learning model }\end{array}$ & $\begin{array}{l}\text { 1. Conduct learning with implementation theory that } \\
\text { supports practical learning. } \\
\text { 2. Conducted using blended learning, a combination of } \\
\text { online and offline. Face-to-face learning can be done } \\
\text { alternately and by applying health protocols. } \\
\text { 3. Students and teachers can master IT better. } \\
\text { 4. The existence of an essential curriculum. } \\
\text { 5. There are strategies, techniques, methods, and } \\
\text { learning applications that students can understand } \\
\text { 6. an effective and efficient learning model to create } \\
\text { learning that is attractive and easy to understand by } \\
\text { students. } \\
\text { 7. The existence of online learning media with } \\
\text { classrooms, WA, via video, modules, and others } \\
\text { with national standards and adjusted to basic } \\
\text { competencies priorities and available time. } \\
\text { 8. Material that is easy to learn, concise, practical, and } \\
\text { communicative. } \\
\text { 9. A sufficient number of books are provided, for } \\
\text { example, each student has at least one book. } \\
\text { 10. The existence of a valid assessment technique } \\
\text { 11. There is a system that is cheap, easy, and can be } \\
\text { used by all students and teachers. } \\
\text { 12. Students continue to participate in learning both } \\
\text { online and offline. }\end{array}$ \\
\hline 2. & $\begin{array}{l}\text { Practical } \\
\text { Learning }\end{array}$ & $\begin{array}{l}\text { 1. The teacher provides and/or makes a } \\
\text { video that is then shared via YouTube or } \\
\text { other platforms, then students are directed } \\
\text { to watch and practice it then make a } \\
\text { practice video and send it to the teacher. } \\
\text { 2. Using the surrounding environment as } \\
\text { practice materials. } \\
\text { 3. Simulation using a laptop or android } \\
\text { based application. } \\
\text { 4. Implemented in schools by forming a } \\
\text { limited number of working groups in turn } \\
\text { and implementing health protocols. } \\
\text { 5. Arrangements for student admission by } \\
\text { shift until evening. } \\
\text { 6. Learning is carried out using the project- } \\
\text { based learning method. } \\
\text { 7. Project-based practical learning with a } \\
\text { target date. } \\
\text { 8. Industrial practices are carried out, } \\
\text { because the school is in an industrial } \\
\text { environment, for integrated practice } \\
\text { subjects with these activities. }\end{array}$ & $\begin{array}{l}\text { 1. The need for media and simulation applications that } \\
\text { can be used as a substitute for direct practice. } \\
\text { 2. The need for videos that contain structured material } \\
\text { according to the competencies based on the } \\
\text { curriculum. } \\
\text { 3. There is a practical worksheet } \\
\text { 4. Using the environment as a practical tool } \\
\text { 5. Learning can be done face to face. } \\
\text { 6. Practical learning project-based offline as a group. } \\
\text { 7. The block system and practical learning can be done } \\
\text { at the end of the semester. } \\
\text { 8. The need for structured learning media so that } \\
\text { student competence is still improved. } \\
\text { 9. The need for an innovative learning model. } \\
\text { 10. There are strategies and learning methods that are } \\
\text { more effective and efficient and flexible. } \\
\text { 11. Can develop the IT skills of teachers and students. }\end{array}$ \\
\hline
\end{tabular}

(Source: Result of data analysis, 2020) 
The implementation of vocational learning requires teachers to develop innovations in learning. Various conditions and learning ideas result in different innovations. The ability of teachers to use technology also influences the innovation made by teachers. Besides, each region has a different status which also affects the implementation of learning. In the end, teachers also have hopes regarding the implementation of learning in this new normal era.

The researchers concluded in two conditions, namely theoretical and practical learning (table 5). In the learning of innovation theory that is carried out by the teacher, among others, by making interactive learning materials in the form of PDF, PPT, and others, using technology as a learning platform, making learning journals. Whereas in practical learning, the teacher innovates by making practical videos which are then distributed to students, using the surrounding environment as a practical tool, using android or windows based practice simulation applications, and utilizing industrial practice activities that can still be implemented in several schools.

The teachers' hope in learning theory and practice is that teachers expect: 1.) A flexible curriculum; 2.) The existence of strategies, methods, media, models, learning techniques that support structured learning and assessment; 3.) Development of teacher and student IT skills; 4.) The existence of videos and applications that support practical learning; and 5.) Learning can be an implementation with blended learning. These teachers hope they can be used as a solution and aspects of developing learning innovations so that learning in the new normal era can still be carried out by following per under standards and achieving overall educational goals.

\section{CONCLUSION}

The implementation of vocational learning in the new normal era needs to be adjusted to the characteristics of the learning being carried out and the abilities of teachers and students in its implementation. A survey conducted on vocational learning resulted in two conclusions, namely the first regarding the implementation of learning and the second regarding the innovation and expectations of teachers in the new normal era of learning.

The implementation of learning found three results, namely learning content, assignment forms, and classroom management. The learning content used by the teacher is share theory. Furthermore, the form of assignment chosen by the teacher leads to summarizing the learning material that has been given. Then for online and offline class management, each teacher chooses for the full and half classes combined with online classes.

The innovation applied by the teacher in the new normal era of learning is the development of technology-based learning materials and using online platforms. In the learning situation of the new normal era, teachers expect a flexible and usable curriculum, develop media, models, methods, standardized learning platforms, which are effective and efficient. In practical learning, teachers expect practical videos and simulation applications that match the expected basic competencies. It is hoped that blended learning can be applied in all schools while still implementing health protocols and limiting the number of students.

\section{REFERENCES}

Anzaku, F. (2011). Library experts speaks on audio-visual material. Lafia: United Nations Educational, Scientific and Cultured Organization (UNESCO) world day for audio-visual heritage.

Apuke, O. D. (2017). Quantitative research methods: A synopsis approach. Kuwait Chapter of Arabian Journal of Business and Management Review, 6(11), 40-47. https://doi.org/10.12816/0040336

Arfika, F., \& Chalid, S. (2017). Penerapan media berbasis video tutorial untuk meningkatkan hasil belajar membuat kampuh siswa kelas X SMK Negeri 1 Stabat. Jurnal Pendidikan Tata Busana, 1((1)), 30-38. 
Ashaver, D., \& Igyuve, S. M. (2013). The use of audio-visual materials in the teaching and learning processes in colleges of education in Benue State-Nigeria. IOSR Journal of Research \& Method in Education (IOSRJRME), 1(6), 44-55. https://doi.org/10.9790/7388-0164455

Budiman, F. A., Soesanto, S., \& Widjanarko, D. (2017). Pengembangan lembar kerja praktik analitik bagi calon guru SMK otomotif. Journal of Vocational and Career Education, 2(1), 50-56. https://doi.org/10.15294/jvce.v2i1.11104

Burhan, N., \& Arifin, Z. (2020). The implementation of block-system learning on the expertise competence of automotive lightweight vehicle engineering in vocational high school. Jurnal Pendidikan Vokasi, 10(1), 80-92. https://doi.org/10.21831/jpv.v10i1.30378

Chieke, J. C., Ewelum, J. N., \& Madu, C. O. (2017). Determination of auditory and visual learning styles of adult learners in adult literacy centres in Anambra State, Nigeria. IOSR Journal of Research \& Method in Education (IOSR-JRME), 7(3), 30-33. https://doi.org/10.9790/73880703053033

Cristea, G. (2015). Class management as methodology of general didactics/general theory of instruction. Procedia - Social and Behavioral Sciences, 180(November 2014), 150-156. https://doi.org/10.1016/j.sbspro.2015.02.098

Desrianti, I. D., Rahardja, U., \& Mulyani, R. (2011). Audio visual as one of the teaching resources on llearning. CCIT (Creative Communication and Innovative Technology) Journal, 5(40), 124-144. https://doi.org/10.33050/ccit.v5i2.145

Gohiya, P., \& Gohiya, A. (2020). E -learning during Covid 19 Pandemic. International Journal of Future Generation Communication and Networking, 13(2), 4-9. https://doi.org/10.21203/rs.3.rs-29575/v1

Hughes, C., Costley, J., \& Lange, C. (2019). The effects of multimedia video lectures on extraneous load. Distance Education, 40(1), 54-75. https://doi.org/10.1080/01587919.2018.1553559

Kausar, G. (2013). Students' perspective of the use of audio visual aids in Pakistan. International Proceedings of Economics Development and Research, 68(3), 73-77. https://doi.org/10.7763/IPEDR

Lase, D. (2019). Education and industrial revolution 4.0. JURNAL HANDAYANI PGSD FIP UNIMED, 10(1), 48-62. https://doi.org/10.24114/jh.v10i1.14138

Lassoued, Z., Alhendawi, M., \& Bashitialshaaer, R. (2020). An exploratory study of the obstacles for achieving quality in distance learning during the covid-19 pandemic. Education Sciences, 10(9), 1-13. https://doi.org/10.3390/educsci10090232

Ode, E. O. (2014). Impact of audio-visual (AVs) resources on teaching and learning in some selected private secondary schools in Makurdi. International Journal of Research in Humanities, Arts and Literature (IMPACT: IJRHAL), 2(5), 195-202. http://paper.researchbib.com/view/paper/17613

Olube, F. K. (2015). Primary school pupils' response to audio-visual learning process in PortHarcourt. Journal of Education and Practice, 6(10), 118-123. https://eric.ed.gov/?id=EJ1081684

Osuagwu, L. (2020). Research methods: Issues and research direction. Business and Management Research, 9(3), 46-55. https://doi.org/10.5430/bmr.v9n3p46

Rupawati, D., Noviani, L., \& Nugroho, J. A. (2017). Penerapan media pembelajaran audio visual untuk meningkatkan hasil belajar ekonomi. Prosiding Seminar Pendidikan Ekonomi Dan Bisnis, 3(1), 21-30. https://jurnal.fkip.uns.ac.id/index.php/snpe/article/view/10638

Sargin, S. A., Baltaci, F., Bicici, H., \& Yumusak, A. (2015). Determining of vocational school student's attitudes toward the puzzle method. Procedia - Social and Behavioral Sciences, 174, 2856-2861. https://doi.org/10.1016/j.sbspro.2015.01.979 
Seçer, Ş. Y. E., Şahin, M., \& Alcı, B. (2015). Investigating the effect of audio visual materials as warm-up activity in aviation english courses on students' motivation and participation at high school level. Procedia - Social and Behavioral Sciences, 199, 120-128. https://doi.org/10.1016/j.sbspro.2015.07.495

Sugiani, S., Syahbudi, I., \& Handayani, W. (2020). Comparison of audio-visual learning effectiveness with conventional media on student learning outcomes in the operation of lathe machine lesson for class XI students of SMK Private Satrya Budi I Perdagangan. International Journal of Resarch and Review, 7(3), 37-43. https://www.ijrrjournal.com/IJRR_Vol.7_Issue.3_March2020/IJRR005.pdf 